\title{
Livros
}

\section{Por novos paradigmas nas ciências do homem}

A subversão do ser. Identidade, mundo, tem-
po, espaço: fenomenologia de uma mutação Mauro Maldonato. São Paulo: Editora Fundação Peirópolis, 2001. 197 páginas. ISBN: 85-85663-48-0

\section{A inteligência da complexidade}

Edgar Morin e Jean-Louis Le Moigne. São Paulo: Editora Fundação Peirópolis, 2000. 263 páginas. ISBN: 85-85663-42-1

\section{Novos paradigmas, cultura e subjetividade}

Dora Fried Schnitman (org.). Porto Alegre: Editora Artes Médicas, 1996. 294 páginas. ISBN: 85-7307-167-2

\section{Processos humanos de mudança: as bases científicas da psicoterapia}

Michael J. Mahoney. Porto Alegre: Editora Artes Médicas, 1998. 457 páginas. CDU 159.922

Os quatro livros que reúno propõem-se a apontar o pensamento científico clássico como paradigma insuficiente para esgotar o entendimento das variedades do fenômeno humano, propondo, de forma bem fundamentada, novas propostas conceituais ou mesmo novos paradigmas que o façam de forma, a um só tempo, mais aberta e abrangente.

Entenda-se por pensamento científico clássico aquele derivado de princípios como: o de ordem, segundo o qual, para Edgar Morin, "a desordem aparente era considerada como o fruto da nossa ignorância provisória”, partindo-se de um a priori de uma ordem necessária a reger o universo, concepção aristotélico-tomista de inspiração metafísica e determinista; o da separabilidade, noção cartesiana de que, para estudar um fenômeno, deve-se decompô-lo em elementos simples, atitude, aliás, tributária da hiperespecialização disciplinar contemporânea; e o da lógica indutivo-dedutiva, sustentada pelos princípios lógicos e ontológicos de Aristóteles, Leibniz e Wolff da identidade, da não-contradição e do terceiro excluído.

Ora, todos esses princípios nem sempre se constituem com adequado valor heurístico, ou seja, não permitem compreensão e previsibilidade tanto para sistemas físico-químicos quanto biológicos e, por decorrência, menos ainda para o ser humano, complexa interação dinâmica e polifônica dos sistemas anteriores com a cultura em que se insere.

Ilustremos:

- a agitação molecular desordenada, descrita inicialmente pela termodinâmica, as descobertas da microfísica, da cosmo-
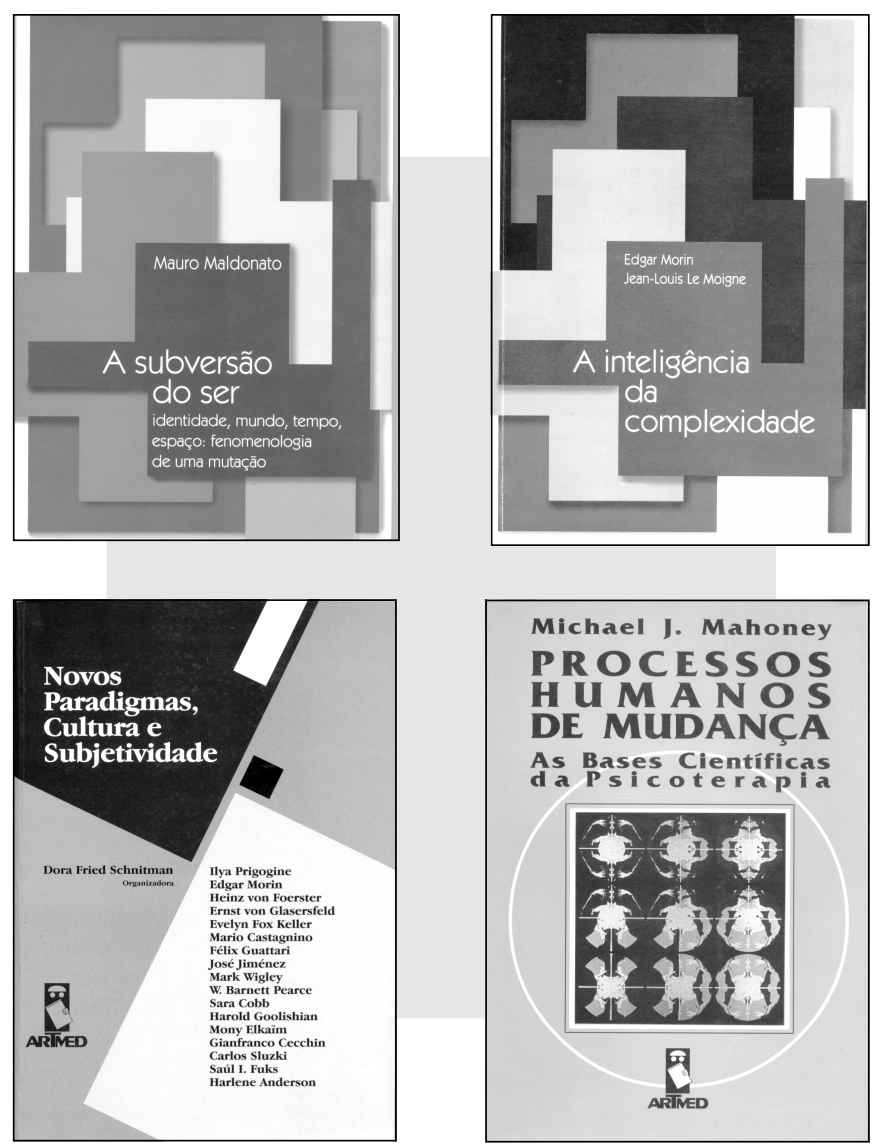

física e da física do caos, ao longo do século XX, puseram por terra o pressuposto da ordem;

- vindo representar o princípio da separabilidade, a crescente hiperespecialização biologista da psiquiatria, na segunda metade do século XX, reação extrema ao psicologismo reducionista anterior, embora permita controlar melhor os sintomas dos pacientes, não cura suas doenças, cuja gênese ou história natural não parecem ainda passíveis de transformação por qualquer procedimento único, não integrado a outros;

- as frustradas tentativas de solução da antinomia determinismo biológico e/ou psicológico versus livre-arbítrio na compreensão da natureza dos atos anti-sociais em alguns transtornos do impulso ou da personalidade, decorrendo disto sérios problemas para uma delimitação suficientemente fundamentada de sua imputabilidade/inimputabilidade, não encontram subsídios suficientes nos princípios da identidade, da nãocontradição e do terceiro excluído.

Isto posto, ocorre-me o ensinamento de Kuhn, de que pro- 
blemas não resolvidos por paradigmas vigentes geram a necessidade e a eclosão de novos paradigmas.

Assim, foi na transição dos séculos XIX para o XX, com o pensamento revolucionário de Nietzsche (com a "morte de Deus", restituindo o homem a si mesmo) e de Husserl (com o engendramento de um método, a fenomenologia, que, segundo Mauro Maldonato, "preferiu continuar assistemática, capaz de uma visão teoreticamente ateorética, que se dá como um inapreensível theorein a-teorético", ensejando a possibilidade de conhecer o homem por dentro, intuindo o que ele é, em sua essência única, conhecimento destituído ao máximo do que dele vem dito previamente na consciência de quem o vê).

Pois, então, a partir da influência desses dois grandes pensadores, é que vemos surgir e se desenvolver algumas e claras confluências:

- a (em verdade, ressurgida) psicopatologia fenomenológica, referencial de Mauro Maldonato, em “A subversão do ser", num belo estudo sobre a identidade e sua fragmentação pelas exigências pós-modernas, estas cegas à alteridade e representadas, entre outros, pelo reducionismo das medicinas epidemiológico-estatística e biológico-molecular;

- o pensamento da complexidade, abordado em "A inteligência da complexidade" e em "Novos paradigmas, cultura e subjetividade", e cujos teóricos apontam como aquele que, entre outras características, e como na visão fenomenológica, não separa o sujeito produtor do conhecimento do objeto a ser conhecido, além de incluir esse objeto num contexto sistêmico, ou seja, em relação de interdependência com o todo em que se insere, cuja configuração não é resultado de uma simples soma de suas partes;

- a psicoterapia construtivista, com interpenetração bastante nítida com os dois paradigmas anteriores e com bases conceituais e científicas profundamente estudadas por Michael Mahoney em "Os processos humanos de mudança”, tomando como ponto de partida uma pergunta ainda sem resposta para os que militam na psicoterapia: os seres humanos podem mudar?

Tomo, a propósito e à guisa de fim, essa pergunta e a transformo: os psiquiatras podem mudar?

Deveríamos poder. Que livros como esses nos permitam, ao menos, pensar em mudanças. Livros ou pensamentos como esse, de Edgar Morin: "O pensamento complexo não é o pensamento onisciente. Pelo contrário, é o pensamento que sabe que sempre é local, situado em um tempo e em um momento. O pensamento complexo não é o pensamento completo; pelo contrário, sabe de antemão que sempre há incerteza. Por isso mesmo escapa do dogmatismo arrogante que reina nos pensamentos não-complexos".

Cumpre-nos tentar.
Mauro Aranha de Lima Psiquiatra 